\title{
UJI FITOKIMIA EKSTRAK KULIT BUAH SALAK (Salacca zalacca) DAN PENGARUH EKSTRAK TERHADAP PERTUMBUHAN BAKTERI Streptococcus mutans DAN JAMUR Candida albicans
}

\author{
Emma Susilowati S*, Agung Rahmadani, Lisna Meylina, Hadi Kuncoro \\ Laboratorium Penelitian dan Pengembangan Kefarmasian "Farmaka Tropis" \\ Fakultas Farmasi, Universitas Mulawarman, Samarinda, Indonesia \\ *Email: emmashabir85@gmail.com
}

\begin{abstract}
Snakefruit (Salacca zalacca) is one of Indonesian native plant that the pericarp of snakefruit can be used because it has activity as an antimicrobial. This study aims to identify the metabolite content of snakefruit pericarp and to investigate the potential of snakefruit pericarp extracts in inhibiting the growth of Streptococcus mutans and Candida albicans. Snakefruit pericarp was extracted by reflux method using ethanol 96\%, and an extract was tested by phytochemical qualitatively and antimicrobial activity of extract was carried out using the well method, by using concentrations are 5, 10, 15, and 20\%. The results showed that the extracts contains secondary metabolites i.e. alkaloids, flavonoids, saponins and tannins. Extract of snakefruit pericarp can inhibit the growth of Streptococcus mutans and Candida albicans at 5\% concentration and the inhibiting activity increased together with higher concentrations of extract.
\end{abstract}

Keywords: Snakefruit pericarp (Salacca zalacca), Metabolite Secondary, Antimicrobial, Well Method.

\begin{abstract}
ABSTRAK
Salak (Salacca zalacca) merupakan salah satu tanaman asli indonesia dimana kulit buahnya dapat dimanfaatkan karena memiliki aktivitas sebagai antimikroba. Penelitian ini bertujuan untuk mengidentifikasi kandungan metabolit pada kulit buah salak serta menyelidiki potensi ekstrak kulit buah salak dalam menghambat pertumbuhan Streptococcus mutans dan Candida albicans. Kulit buah salak diekstraksi dengan metode refluks menggunakan pelarut etanol 96\%, ekstrak yang diperoleh diuji fitokimia secara kualitatif dan pengujian aktivitas antimikroba dilakukan dengan menggunakan metode sumuran, dengan menggunakan konsentrasi ekstrak 5, 10, 15, dan 20\%. Hasil menunjukkan bahwa ekstrak kulit buah salak mengandung golongan metabolit sekunder alkaloid, flavonoid, saponin dan tanin. Serta ekstrak kulit buah salak telah dapat menghambat pertumbuhan Streptococcus mutans dan Candida albicans pada konsentrasi $5 \%$ dan aktivitas penghambatannya semakin tinggi seiring dengan peningkatan konsentrasi ekstrak.
\end{abstract}


Kata Kunci: Kulit Buah Salak (Salacca zalacca), Metabolit Sekunder, Antimikroba, Metode Sumuran

DOI: https://doi.org/10.25026/mpc.v8i1.346

\section{PENDAHULUAN}

Antibakteri dalam definisi yang luas adalah suatu zat yang mencegah terjadinya pertumbuhan dan reproduksi bakteri. Antibakteri biasanya dijabarkan sebagai suatu zat yang digunakan untuk membersihkan permukaan dan menghilangkan bakteri yang berpotensi membahayakan [1].

Salak adalah sejenis palma dengan buah yang biasa dimakan. Tanaman salak dikenal juga, dalam bahasa Inggris disebut snake fruit karena kulitnya mirip dengan sisik ular, sementara nama ilmiahnya adalah Salacca zalacca. Tetapi ada sebagian sumber juga menyebutkan nama ilmiah salak adalah Salacca edulis [2].

Masyarakat di Indonesia telah lama mengenal berbagai jenis tumbuhan obat dan pemanfaatannya untuk menjaga kesehatan dan mengobati berbagai penyakit. Salah satu tanaman yang berkhasiat sebagai obat adalah salak. Bagian dari tumbuhan ini yang berkhasiat adalah kulit buahnya [3].

Kulit buah salak merupakan limbah yang biasanya tidak terpakai lagi. Namun kulit buah salak mengandung nilai gizi berupa protein, karbohidrat, air serta rendah lemak. Kulit buah ini juga mengandung senyawa yang dapat berguna sebagai antibakteri. Hasil uji fitokimia menunjukkan bahwa daging dan kulit buah salak mengandung senyawa flavonoid, tanin dan alkaloid [3].

Hal ini juga telah dibuktikan pada penelitian (Laffiani, 2017)[4] yang membuktikan bahwa kulit salak dapat berperan sebagai antimikroba yang dapat menghambat pertumbuhan dari jamur
Candida albicans menggunakan plat resin gigi tiruan sebagai media. Penelitian Rahmah [3] menggunakan metode difusi cakram menunjukkan terjadi penghambatan pertumbuhan bakteri E.coli seiring dengan pertambahan konsetrasi ekstrak kulit buah salak. Sehingga hal ini menjadi topik yang menarik untuk diteliti.

Berdasarkan penelitian sebelumnya tentang buah salak lebih terfokus pada daging buah dan biji dari buah salak sedangkan untuk kulitnya masih sangat minim. Maka dari itu dilakukan penelitian mengenai kulit buah salak terhadap mikroba lain dan metode berbeda untuk memberikan informasi bahwa kulit salak dapat dibuktikan mempunyai potensi antimikroba secara ilmiah, sehingga salak di masa yang akan datang akan menjadi buah yang dapat dimanfaatkan secara optimal, yaitu sebagai makanan dari daging buahnya dan sebagai obat pada kulitnya.

\section{METODE PENELITIAN}

\section{Bahan}

Buah salak diambil dari perkebunan didaerah Sebulu, Kutai Kartanegara, Kalimantan Timur. Etanol 96\%, Nutrient Agar (Merck), Potato Dextrose Agar (Merck), aquades, asam asetat glasial (Merck), asam sulfat (Merck), asam klorida pekat (Merck), asam klorida $2 \mathrm{~N}, \mathrm{FeCl}_{3} 1 \%$, pereaksi mayer, pereaksi dragendorf, pereaksi wagner, dan serbuk magnesium (Merck).

\section{Proses Ekstraksi}

Buah salak (Salacca zalacca) sebanyak $20 \mathrm{~kg}$ dikupas dan diambil 
kulitnya. Setelah itu kulit salak dikeringkan selama $2 \times 24$ jam kemudian dicuci bersih dan dioven dengan suhu $50^{\circ} \mathrm{C}$ selama 7 jam. Setelah kering simplisia dibuat menjadi serbuk dan diekstraksi dengan metode refluks menggunakan pelarut etanol $96 \%$. Kemudian ekstrak dipekatkan menggunakan alat rotary evaporator (Buchi) sehingga diperoleh ekstrak kental.

\section{Uji Fitokimia}

\section{Identifikasi Alkaloid}

Sebanyak $2 \mathrm{~mL}$ larutan ekstrak ditambahkan dengan $5 \mathrm{~mL} \mathrm{HCl} 2 \mathrm{~N}$. Larutan yang didapat kemudian dibagi 3 tabung reaksi. Tabung pertama ditambahkan pereaksi Wagner sebanyak 3 tetes, tabung kedua ditambahkan pereaksi Dragendroff sebanyak 3 tetes, dan tabung ketiga ditambahkan pereaksi Mayer sebanyak 3 tetes. Terbentuknya endapan jingga sampai merah coklat pada tabung pertama, endapan jingga pada tabung kedua dan endapan putih hingga kekuningan pada tabung ketiga menunjukkan adanya alkaloid [5].

\section{Identifikasi Flavonoid}

Sebanyak $2 \mathrm{~mL}$ larutan ekstrak, didihkan selama 5 menit. Kemudian ditambahkan sedikit serbuk $\mathrm{Mg}$ dan $1 \mathrm{~mL}$ $\mathrm{HCl}$ pekat, kemudian dikocok. Uji positif ditunjukkan oleh terbentuknya warna merah, kuning atau jingga [6].

\section{Identifikasi Saponin}

Saponin dapat dideteksi dengan uji busa dalam air panas. Busa yang stabil akan terus terlihat selama 5 menit dan tidak hilang pada penambahan 1 tetes $\mathrm{HCl} 2 \mathrm{~N}$ menunjukkan adanya saponin [7].

\section{Identifikasi Steroid dan Terpenoid}

Sebanyak $2 \mathrm{~mL}$ larutan ekstrak ditambahkan $\mathrm{CH}_{3} \mathrm{COOH}$ glasial sebanyak 10 tetes dan $\mathrm{H}_{2} \mathrm{SO}_{4}$ pekat sebanyak 2 tetes. Larutan dikocok perlahan dan biarkan selama beberapa menit. Steroid memberikan warna biru atau hijau, sedangkan triterpenoid memberikan warna merah atau ungu [8].

\section{Identifikasi Tanin}

Sebanyak $2 \mathrm{~mL}$ larutan ekstrak ditambahkan 3-5 tetes larutan Besi (III) Klorida $1 \%$. Perubahan yang terjadi diamati, terbentuknya warna biru tua atau hitam kehijauan menunjukkan adanya senyawa tanin [9].

\section{Proses Sterilisasi Alat dan Medium}

Alat-alat kaca yang digunakan terlebih dahulu dicuci bersih dan dikeringkan, setelah itu alat-alat seperti tabung reaksi dan erlenmeyer dibuatkan tutup dari kasa dan kapas. Setelah itu dibungkus menggunakan kertas. Untuk medium terlebih dahulu ditimbang nutrient agar sebanyak 6,25 gram dan potato dextrose agar sebanyak 9,975 gram kemudian dilarutkan dengan aquades sebanyak $250 \mathrm{ml}$ dalam erlenmeyer masing-masing, diaduk sambil dipanaskan diatas hot plate sampai warna medium menjadi bening. Setelah itu erlenmeyer diberi tutup dari kasa dan kapas. Kemudian alat yang telah dibungkus dan medium dimasukkan dalam autoclave disterilkan dengan suhu $121^{\circ} \mathrm{C}$ selama 15 menit.

\section{Pembiakkan Mikroba}

Bakteri dan jamur yang digunakan harus dibiakkan terlebih dahulu dengan cara mengambil bakteri dan jamur dari biakan murni dengan ose bulat, dan menggoresnya diatas medium baru dengan menggunakan metode miring. Penggoresan diulangi sebanyak 3 kali. Kemudian masing-masing biakan bakteri diinkubasi selama $1 \times 24$ jam dengan suhu $37^{\circ} \mathrm{C}$. Sedangkan biakan jamur diinkubasi selama $2 \times 24$ jam dengan suhu ruang.

\section{Pembuatan Suspensi Mikroba}


Mikroba yang telah dibiakan diambil dan diberi $9 \mathrm{ml} \mathrm{NaCl} 0,9 \%$, kemudian dihomogenkan. Setelah itu dari biakan murni tadi diambil sebanyak 2,5 $\mathrm{ml}$ dan ditambahkan dengan $7,5 \mathrm{ml} \mathrm{NaCl}$ $0,9 \%$ didalam tabung reaksi steril dan dihomogenkan. Dari tabung reaksi tersebut diambil $0,5 \mathrm{ml}$ untuk pengujian antimikroba.

\section{Pengujian Antimikroba}

Metode yang digunakan adalah metode difusi agar dengan cara perforasi. Sebanyak $0,5 \mathrm{~mL}$ suspensi bakteri uji dicampurkan ke dalam 9,5 mL media pada saat suhu $45^{\circ} \mathrm{C}$ kemudian dihomogenkan hingga suspensi bakteri uji bercampur rata dengan media. Setelah media uji tersebut padat, media dilubangi menggunakan pencadang, lubang tersebut diisi dengan $100 \mu \mathrm{L}$ masing-masing konsentrasi ekstrak kulit buah salak. Setelah itu cawan diinkubasi dan diamati zona bening pada cawan kemudian diukur menggunakan mikometer sekrup.

\section{HASIL DAN PEMBAHASAN}

Uji fitokimia ekstrak kulit buah salak ini dilakukan dengan melihat perubahan warna dari sampel yang telah diberi dengan pereaksi yang sesuai. Berdasarkan hasil pengujian fitokimia yang terdapat pada Tabel 1. diketahui bahwa kulit buah salak mengandung alkaloid, flavonoid, saponin, dan tanin.

Tabel 1. Hasil Uji Fitokimia Ekstrak Buah Salak (Salacca zalacca)

\begin{tabular}{llc}
\hline \multicolumn{1}{c}{ Senyawa } & \multicolumn{1}{c}{ Warna } & Hasil \\
\hline Alkaloid: & & \\
Pereaksi Dragendorf & Endapan jingga & + \\
Pereaksi Mayer & Endapan putih kekuningan & + \\
Pereaksi Wagner & Endapan jingga/merah kecoklatan & + \\
Flavonoid & Merah/kuning/jingga & + \\
Saponin & Busa stabil (selama 5 menit dan setelah ditetesi HCl 2N) & + \\
Steroid & Biru/hijau & - \\
Terpenoid & Merah/ungu & - \\
Tanin & Biru tua/hitam kehijauan & + \\
\hline
\end{tabular}

Keterangan:

$+=$ Terjadi perubahan warna

- = Tidak terjadi perubahan warna

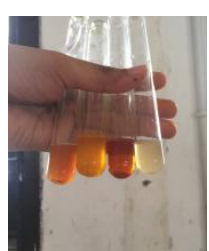

(a)

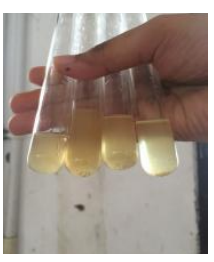

(b)

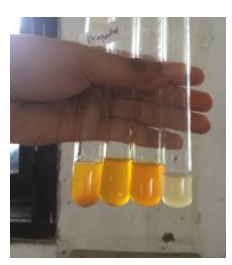

(c)

Gambar 1. Identifikasi Alkaloid (a) Menggunakan Pereaksi Wagner (b) Menggunakan Pereaksi Mayer (c) Menggunakan Pereaksi Dragendorf 


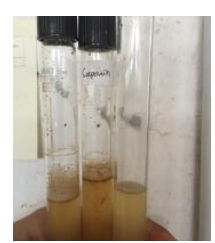

(a)

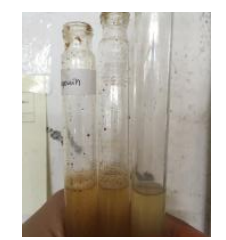

(b)

Gambar 2. Identifikasi Saponin (a) Busa Stabil Setelah didiamkan selama 5 menit (b) Busa stabil Setelah Penambahan $\mathrm{HCl} 2 \mathrm{~N}$ Sebanyak 1 Tetes

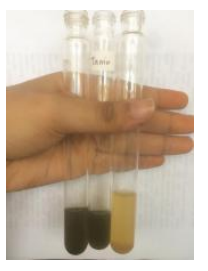

(a)

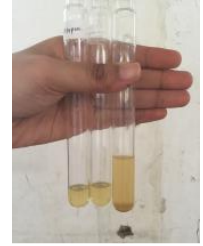

(b)

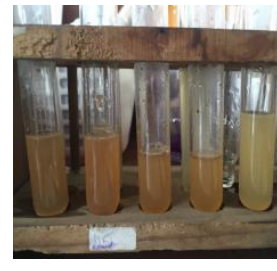

(c)

Gambar 3. (a) Identifikasi Tanin (b) Identifikasi Steroid dan Terpenoid

(c) Identifikasi Flavonoid

Tabel 2. Hasil Pengukuran Diameter Zona Hambat Ekstrak Kulit Buah Salak (Salacca zalacca) terhadap Mikroba Uji

\begin{tabular}{ccc}
\hline Mikroba Uji & Konsentrasi Ekstrak (\%) & $\begin{array}{c}\text { Rata-rata Diameter Zona Hambat } \\
(\mathrm{mm}) \pm \text { SD }\end{array}$ \\
\hline \multirow{3}{*}{ S. mutans } & 5 & $12.260 \pm 0.831$ \\
& 10 & $14.482 \pm 0.647$ \\
& 15 & $15.404 \pm 0.501$ \\
C. albicans & 20 & $16.575 \pm 0.619$ \\
\hline & 5 & $11.308 \pm 0.602$ \\
& 10 & $14.478 \pm 0.737$ \\
& 15 & $16.091 \pm 0.561$ \\
& 20 & $14.579 \pm 4.694$ \\
\hline
\end{tabular}

Pengujian antimikroba ekstrak kulit buah salak (Salacca zalacca) pada penelitian ini menggunakan metode difusi sumuran. Dimana setelah masa inkubasi diamati zona bening pada masing-masing cawan petri yang menunjukkan bahwa terdapat pengaruh ekstrak terhadap penghambatan pertumbuhan dari masingmasing mikroba uji yang digunakan. Pada metode sumuran terjadi proses osmolaritas dari konsentrasi ekstrak yang lebih tinggi dari metode difusi cakram, setiap lubang diisi dengan konsentrasi ekstrak maka osmolaritas terjadi lebih menyeluruh dan lebih homogen serta konsentrasi ekstrak lebih kuat dan lebih tinggi untuk menghambat pertumbuhan mikroba [10].

Berdasarkan hasil pada Tabel 2 . dapat dilihat diameter zona hambat dari masing-masing konsentrasi ekstrak yang diuji. Dilihat dari rata-rata diameter zona 
hambat pada masing-masing mikroba uji menurut Davis dan Stout (1971) dapat dikategorikan diameter zona hambat yang dihasilkan termasuk kategori kuat. Hal ini dapat dikaitkan dengan hasil dari uji fitokimia ekstrak kulit buah salak dimana pada hasil uji tersebut ekstrak positif mengandung flavonoid, tanin dan saponin yang sebagaimana telah diketahui merupakan senyawa-senyawa yang dapat berperan sebagai antimikroba.

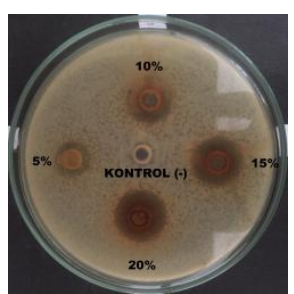

(R2)

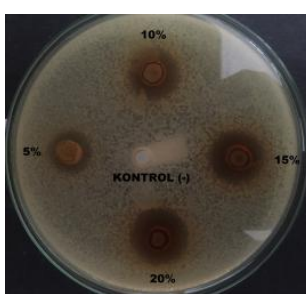

(R3)

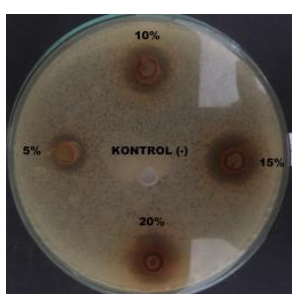

(R1)

Gambar 4. Uji Antimikroba terhadap S. mutans
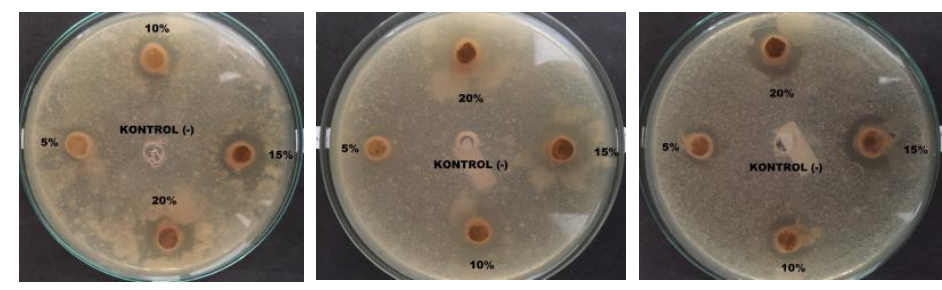

(R2)

(R3)

Gambar 5. Uji Antimikroba terhadap C. albicans

Flavonoid berfungsi sebagai antimikroba dengan cara membentuk senyawa kompleks terhadap protein ekstraseluler yang menganggu integritas membran sel bakteri. Senyawa flavonoid diduga mempunyai aktivitas antibakteri dengan mekanisme kerja adalah mendenaturasi protein sel bakteri dan merusak membran sel mikroba tanpa dapat diperbaiki lagi [12]. Sedangkan senyawa saponin dapat bekerja sebagai antimikroba dengan cara merusak membran sitoplasma dan membunuh sel mikroba. Saponin memiliki aktivitas antimikroba dan antifungi berspektrum luas. Gugus lipofilik pada saponin dapat merusak membran sel mikroba [12]. Dan tanin merupakan salah satu senyawa kimiawi yang termasuk dalam golongan polifenol yang diduga dapat mengikat salah satu protein yang dimiliki oleh bakteri yaitu adhesin dan apabila hal ini terjadi maka dapat merusak ketersediaan reseptor pada pemukaan sel bakteri. Tanin juga telah dibuktikan dapat membentuk senyawa kompleks yang irreversible dengan prolin, suatu protein lengkap, yang mana ikatan ini mempunyai efek penghambatan sintesis protein untuk pembentukan dinding sel [12]. 


\section{KESIMPULAN}

Berdasarkan hasil pengujian yang telah dilakukan, maka dapat disimpulkan bahwa hasil uji fitokimia ekstrak kulit buah salak (Salacca zalacca) mengandung metabolit sekunder golongan flavonoid, saponin dan tannin. Hasil pengujian antimikroba dari ekstrak kulit buah salak (Salacca zalacca) menunjukkan ekstrak dapat menghambat pertumbuhan dari Streptococcus mutans dan Candida albicans yang termasuk dalam kategori penghambatan kuat.

\section{DAFTAR PUSTAKA}

[1] Volk, W.A., Wheeler, M.F. 1990. Mikrobiologi Dasar Edisi V Jilid 2. Penerbit Erlangga. Jakarta.

[2] Dalimartha, S. 2009. Atlas Tumbuhan Obat Indonesia Jilid I. Trubus Agriwidia. Jakarta.

[3] Rahmah, Umi. 2016. Pengaruh Ekstrak Kulit Buah Salak (Salacca zalacca (Gaertn.) Voss) Terhadap Pertumbuhan Escherichia coli. Artikel Ilmiah. Fakultas Keguruan dan Ilmu Pengetahuan Universitas Jambi.

[4] Laffiani, Yunita. 2017. Efektivitas Ekstrak Kulit Salak Pondoh (Salacca zalacca) terhadap Pertumbuhan Candida albicans pada Plat Resin Akrilik. Karya Tulis Ilmiah. UMY Yogyakarta.

[5] Simaremare, Eva Susanty. 2014. Skrining Fitokimia Etanol Daun Gatal (Laportea decumana (Roxb.) Wedd). Pharmacy. Volume 1 (01). ISSN 1693-3591.

[6] Illing, Ilmiat., Wulan Safitri dan Erfiana. 2017. Uji Fitokimia Ekstrak Buah Dengen. Jurnal Dinamika. Volume 08 (01). E-ISSN 2503-4863.
[7] Alasa, Astrid natalia., Syariful Anam dan Jamaluddin. 2017. Analisis Kadar Total Metabolit Sekunder Ekstrak Etanol Daun Tamoenju (Hibiscus surattensis L.). Kovalen. Volume 3 (3). E-ISSN 2477-5398.

[8] Najoan, Jelly Juliana,. Max John R. Runtuwene dan Defny S. Wewengkang. 2016. Uji Fitokimia dan Aktivitas Antioksidan Ekstrak Etanol Daun Tiga (Allophylus cobbe L.). Pharmacon Jurnal Ilmiah Farmasi. Volume 5 (01). ISSN 23022493.

[9] Lumowa, Sonja V. T dan Syahril Bardin. 2018. Uji Fitokimia Kulit Pisang Kepok (Musa paradisiaca L.) Bahan Alam sebagai Pestisida Nabati Berpotensi Menekan Serangan Hama Tanaman Umur Pendek. Jurnal Sains dan Kesehatan. Volume 1 (09). PISSN 2303-0267.

[10]Misna, dan Khusnul Diana. 2016. Aktivitas Antibakteri Ekstrak Kulit Bawang Merah (Allium cepa L.) terhadap Bakteri Staphylococcus aureus. Galenika Journal of Pharmacy. Volume 2 (02). ISSN : 2442-8744.

[11]Davis, W.W. and T.R Stout. 1971. Disc plate methods of microbiological antibiotic assay. J. Microbiology. (4):659-665.

[12] Muwarni, dan Y Fatisa. 2011. Uji Efek Antimikroba Ekstrak Kulit Pohon Rambutan (Nephellium lappaceum L) Terhadap Escherichia coli Secara In Vitro. Laboratorium Mikrobiologi dan FAAL FKUB. Malang. Halaman 8. 